\title{
PELAKSANAAN PENGADAAN BARANG/JASA SECARA ELEKTONIK (E-PROCUREMENT) PADA SATUAN KERJA PELAKSANAAN JALAN NASIONAL PROVINSI KALIMANTAN TENGAH
}

\author{
Implementation of Electronic Procurement (e-procurement) in the National Road \\ Implementation Task Force of Central Kalimantan Province
}

\section{Rooswandy Juniawan Muhamad Yusuf Junaidi}

Universitas Muhammadiyah Palangkaraya, Palangka Raya, Central Kalimantan, Indonesia email: rooswandy@gmail.com

Kata Kunci:

Pelaksanaan

Pengadaan

Barang/Jasa

Keywords:

Implementation

Procurement

Goods/Services

\begin{abstract}
Abstrak
Penelitian ini bertujuan untuk menganalisis pelaksanaan dan mengidentifikasi faktor-faktor penghambat Pelaksanaan Pengadaan Barang/Jasa Secara Elektonik (e-procurement) Pada Satuan Kerja Pelaksanaan Jalan Nasional Provinsi Kalimantan Tengah. Sasaran yang diinginkan dalam penelitian, peneliti memberikan batasan masalah Pelaksanaan tender elektronik untuk pekerja konstruksi (jalan/Jembatan) di Satuan Kerja Pelaksanaan Jalan Nasional Provinsi Kalimantan Tengah.
\end{abstract}

Pendekatan penelitian dalam penelitian ini berjenis deskriptif kualitatif yang bertujuan menggambarkan tentang kompleksitas dan kedinamisan dalam pengadaan barang/jasa elektronik. Pengumupulan data yang dilakukan melalui observasi, wawancara dan dokumentasi. Adapun yang diwawancarai adalah kepala satuan kerja, pejabat pembuat komitmen, asisten satker, bendahara, dan pegawai lainnya yang berkaitan dengan lelang elektonik pada Satuan Kerja Pelaksana Jalan Nasional Provinsi Kalimantan Tengah.

Hasil Penelitian menunjukkan kesimpulan bahwa Pelaksanaan Pengadaan Barang/jasa secara elektronik pada satuan kerja pelaksanaan jalan nasional Provinsi Kalimantan Tengah telah dilakukan sejak beberapa tahun terakhir. Seluruh tahapan lelang secara elektonik itu melalui proses yang panjang yakni dengan 14 tahapan yang semuannya transparan menggunakan sistem yang bisa diakses untuk publik. Namun Faktor penghambat pelaksanaan pengadaan barang/jasa secara elektronik (e-procurement) pada satuan kerja pelaksanaan jalan nasional Provinsi Kalimantan Tengah yaitu : I) SDM, yaitu kurangnya keahlian dalam menjalankan aplikasi Sistem Pengadaan Secara Elektronik (SPSE) serta kurangnya pegawai yang memiliki Sertifikat Pengadaan Barang Jasa yang merupakan syarat mutlak untuk menjadi Pokja Pemilihan/Pejabat Pengadaan. 2) Teknologi, kapasitas jaringan internet yang menyebabkan kecepatan akses internet menjadi lambat.

\begin{abstract}
This research aims to analyze the implementation and identify the inhibitory factors of the Implementation of the Procurement of Goods /Services Electonic (e-procurement) in the National Road Implementation Task Force of Central Kalimantan Province. The desired target in the study, the researchers gave a limitation of the problem the implementation of electronic tenders for construction workers (roads/bridges) in the National Road Implementation Task Force of Central Kalimantan Province.
\end{abstract}

The research approach in this study is a type of qualitative descriptive that aims to describe the complexity and dynamic in the procurement of electronic goods/services. Data collection was conducted through observations, interviews, and documentation. The interviewees were the head of the task force, the commitment-making officer, the task force assistant, the treasurer, and other employees related to the electoral auction in the Central Kalimantan Province National Road Implementing Task Force.

The results of the study show the conclusion that the implementation of procurement of goods /services electronically in the national road implementation taskforce of Central Kalimantan Province has been carried out for the last few years. All stages of the auction are electonic through a long process of 14 stages that all transparent using a system that can be accessed for the public. However, the factor of inhibiting the implementation of electronic procurement of goods /services (e-procurement) in the national road implementation taskforce of Central Kalimantan Province is I) HR, namely the lack of expertise in running the application of Electronic Procurement System (SPSE) as well as the lack of employees who have a Certificate of Procurement of Service Goods which is an absolute requirement to become Pokja Election I Procurement Officer. 2) Technology, internet network capacity that causes internet access speed to be slow. 


\section{PENDAHULUAN}

Penelitian ini berfokus pada problematika dari pengadaan barang/jasa secara elektronik pada Satuan Kerja Pelaksanaan Jalan Nasional Wilayah I Provinsi Kalimantan Tengah. Proses pengadaaan barang/jasa yang pelaksanaanya dilakukan secara eletronik yang bebasis web/internet dengan memanfatkan fasilitas teknologi komuniksi dan informasi. Tujuan dari pengadaan barang/jasa secara eletronik adalah menjamin efisiensi, efektifitas, transparansi dan akuntabilitas dalam pembelanjaan uang negara.

$\mathrm{Hal}$ ini sejalan dengan salah satu tuntutan reformasi birokrasi di Indonesia yakni peningkatan pengadaan barang/jasa bagi pemerintah sebagai akibat dari banyaknya kasus korupsi, kolusi, dan nepotisme, serta inefisiensi dalam proses pengadaan tersebut. Reformasi dalam pengadaan kemudian diwujudkan dalam pelaksanaan pengadaan secara elektronik (e-procurement).

Kemajuan teknologi informatika yang begitu pesat, membuka pemikiran untuk pengembangan e-government sebagai salah satu cara untuk mengelola administrasi publik dengan lebih cepat, murah dan transparan. Salah satu bentuk e-government yang dilakukan adalah layanan publik dalam pengadaan barang dan jasa di instansi pemerintah menggunakan Sistem Pelelangan Secara Elektronik (SPSE) atau yang lebih dikenal dengan e-procurement. Instrumen ini memanfaatkan fasilitas teknologi komunikasi dan informasi meliputi pelelangan umum secara elektronik yang diselenggarakan Layanan Pengadaan Secara Elektronik (LPSE).

Penerapan e-procurement bertujuan untuk melakukan efisiensi biaya berupa penurunan biaya operasional dan penurunan risiko terjadinya penyimpangan dalam pengadaan barang dan jasa. Investasi yang dilakukan perlu dinilai kelayakannya dengan mengukur keefektifan implementasi eprocurement. Analisis atas proses bisnis menunjukkan bahwa e-procurement dapat meningkatkan transparansi, sehingga dapat mengurangi risiko terjadinya penyimpangan dalam proses pengadaan barang/jasa.

Dari pengamatan yang dilakukan oleh peneliti bahwa selama ini ada berbagai permasalahan dalam pelaksanan pengadaan barang/jasa pada satuan kerja pelaksanaan jalan nasional seperti tidak banyak pegawai yang mengerti dan paham menjalankan aplikasi eprocurement yaitu SPSE (Sistem Pengadaan Secara Elektronik) sehingga memperlambat proses pengadaan. Serta masih sedikitnya pegawai yang memiliki Sertifikat Keahlian Pengadaan Barang/Jasa.

Selain itu, Kesiapan Infrastruktur Teknologi (internet) jaringan internet yang lambat menghambat proses upload dan download data, khususnya data-data yang memiliki kapasitas file yang besar (>100Mb) yang memperlambat pelaksanan pengadaan barang/jasa pada satuan kerja pelaksanaan jalan nasional.

Maka dari permasalahan yang telah diungkapkan, peneliti tertarik untuk mengangkat Pelaksanaan Pengadaan Barang/Jasa Secara Elektonik (e-procurement) Pada Satuan Kerja Pelaksanaan Jalan Nasional Provinsi Kalimantan Tengah. Adapun rumusan masalah dalam penelitian ini yaitu :

I) Bagaimana Pelaksanaan Pengadaan Barang/Jasa Secara Elektonik (e-procurement) Pada Satuan 
Kerja Pelaksanaan Jalan Nasional Provinsi Kalimantan Tengah?

2) Apa saja faktor-faktor yang menghambat Pelaksanaan Pengadaan Barang/Jasa Secara Elektonik (e-procurement) Pada Satuan Kerja Pelaksanaan Jalan Nasional Provinsi Kalimantan Tengah?

\section{METODOLOGI}

Penelitian ini berjenis deksriftif kualitatif yang bertujuan menggambarkan tentang kompleksitas dan kedinamisaan pelaksanaan barang/jasa elektronik. Lokasi penelitian ini berada di Satuan Kerja Pelaksanaan Jalan Nasional Provinsi Kalimantan Tengah dan Balai Pelaksana Pemilihan Jasa Konstruksi Wilayah Provinsi Kalimantan Tengah.

Pengumpulan data dalam penelitian ini peneliti menggunakan teknik studi lapangan (field research) yaitu teknik pengumpulan data yang dilakukan dengan cara peneliti terjun secara langsung ke lapangan tempat lokasi penelitian dilakukan. Teknik Pengumpulan data yang digunakan yaitu observasi, wawancara, dokumentasi, dan studi literatur.

Observasi yang peneliti lakukan adalah satuan kerja pelaksana jalan nasional Provinsi Kalimantan Tengah beserta sistem yang dilakukan pada lelang elektroniknya. Adapun yang diwawancarai adalah kepala satuan kerja, pejabat pembuat komitmen, asisten satker, bendahara, dan pegawai lainnya yang berkaitan dengan lelang elektonik pada Satuan Kerja Pelaksana Jalan Nasional Provinsi Kalimantan Tengah. Serta dokumen yang dipelajari dalam penelitian ini yang berkaitan dengan regulasi, SOP, profil, Stuktur,
Laporan Pelaksanan Pengadaan, dll yang dapat mendukung penelitian ini.

\section{HASIL DAN PEMBAHASAN}

Pengadaan Barang/Jasa Pemerintah mempunyai peran penting dalam pelaksanaan pembangunan nasional untuk peningkatan pelayanan publik dan pengembangan perekonomian nasional dan daerah. Penyelenggaraan pengadaan barang/jasa pemerintah secara elektronik di Satuan Kerja Pelaksanaan Jalan Nasional Provinsi Kalimantan Tengah memanfaatkan Sistem Pengadaan Barang/Jasa Elektronik (SPSE) dan sistem pendukung. SPSE merupakan aplikasi yang dikembangkan oleh LKPP untuk diterapkan pada K/L/Pemerintah Daerah di seluruh Indonesia dengan ruang lingkup perencanaan pengadaaan, persiapan pengadaan, pemilihan penyedia, pelaksanaan kontrak, serah terima pekerjaan, pengelolaan penyedia, dan katalog elektronik. Dalam pengelolaannya, SPSE dan sistem pendukung dikelola oleh Layanan Pengadaan Barang/Jasa Secara Elektronik (LPSE) Kementerian Pekerjaan Umum dan Perumahan Rakyat.

Tabel 4.2 Laporan Pelaksanaan Pengadaaan Melalui E-Procurement SATKER PJN Provinsi Kalteng

\begin{tabular}{|c|c|cc|lr|}
\hline TAHUN ANGGARAN & JUMLAH PAKET & \multicolumn{2}{|c|}{ NILAI PAGU } & \multicolumn{2}{c|}{ NILAI KONTRAK } \\
\hline 2018 & 11 & Rp & $254.753 .780 .500,00$ & Rp & $248.363 .883 .000,00$ \\
\hline 2019 & 14 & $R p$ & $320.682 .373 .000,00$ & Rp & $305.935 .640 .000,00$ \\
\hline 2020 & 11 & $R p$ & $378.063 .943 .000,00$ & Rp & $365.621 .334 .000,00$ \\
\hline
\end{tabular}

Berdasarkan Tabel 4.2 Laporan Pelaksanaan Pengadaaan Melalui E-Procurement SATKER PJN Provinsi Kalteng dalam 3 tahun terakhir yaitu tahun 2018, 2019 dan tahun 2020. Pelaksanaan pengadaan eletektonik tersebut menunjukan jumlah paket dalam I tahun dan 
setiap tahunnya ada peningkatan nilai pagu anggaran dan nilai kontrak yang dijalankan. Walaupun dalam laporan tersebut menunjukkan pelaksanaan pengadan melalui E-Procurement, akan tetapi belum menggambarkan proses dan kendala yang terjadi selama melakukan pelelangan tersebut.

Maka dari itu, Peneliti lebih lanjut ingin melihat Pelaksanaan Tender Elektronik untuk Pekerjaan Konstruksi (Jalan/Jembatan) di Satuan Kerja Pelaksanaan Jalan Nasional Provinsi Kalimantan Tengah dengan meninjau dua (2) bidang yang berpengaruh pada pelaksanaan Tender Elektronik yaitu bidang manajemen sumber daya manusia (tingkat kemampuan pegawai) dan bidang insfratuktur teknologi internet (tingkat kapasitas teknologi internet).

I. Sumber Daya Manusia

Dalam proses pengadaan barang dan jasa melalui sistem e-procurement, maka Satuan Kerja Pelaksanaan Jalan Nasional Provinsi Kalimantan Tengah memerlukan sumber daya manusia yang memiliki kemampuan dan keterampilan dalam melaksanakan pekerjaannya. Mengingat faktor terpenting dalam pelaksanaan pengadaan barang/jasa melalui e-procurement adalah sumber daya manusia. Sumber daya manusia ini lebih menyangkut sumber daya manusia yang sudah memenuhi kebutuhan dan memiliki kompetensi yang memadai dalam melaksanakan e-procurement sehingga peneliti ingin melihat kemampuan dan kapasitas dalam pelaksanaan pengadaan barang/jasa melalui eprocurement di Satuan Kerja Pelaksanaan Jalan Nasional Provinsi Kalimantan Tengah.
Dalam teori yang dikemukakan oleh Edward III dikutip oleh Tahir (2014) bahwa Implementasi Kebijakan dipengaruhi oleh beberapa faktor yaitu salah satunya faktor sumber daya manusia. Keberhasilan implementasi kebijakan harus didukung oleh sumber daya dimana sumber daya ini berupa manusia yang memiliki kompetensi implementasi dan sumber daya finansial. Sumber daya manusia yang merupakan salah satu aspek penggerak dalam menjalankan suatu kebijakan. Suatu organisasi akan menuju pengoptimalan tujuan organisasinya jika dapat meningkatkan kinerja pegawai dengan memaksimalkan kemampuan dari pegawainya itu sendiri.

Peneliti melakukan pendalaman mengenai kemampuan sumber daya manusia dalam pelaksanaan pengadaan barang/ jasa melalui e-procurement di Satuan Kerja Pelaksanaan Jalan Nasional Provinsi Kalimantan Tengah dengan melakukan wawancara dengan kepala satuan kerja PJN Kalteng, adapun ungkapan yang disampaikan sebagai berikut :

"Sumber daya manusia dalam pelaksanaan pengadaan barang/ jasa melalui eprocurement bisa dikatakan masih memiliki ketebatasan keahlian dan pemahaman tentang sistem lelang elektronik. Pada awalnya memang hanya optimis dengan tuntutan untuk melaksanakan sistem pelelangan secara full e-procurement. Akan tetapi dalam berjalannya waktu, memang disadari bahwa SDM yang ada belum maksimal melaksanakn sistem lelang elektonik tersebut".

Dari pernyataan yang diungkapkan kepala satuan kerja sebagai penanggung jawab program tersebut menyatakan keterbatasan 
kemampuan, hal itu sejalan yang diungkapkan oleh bendahara yang mengatakan :

"Memang saya akui bahwa masih banyak pegawai yang belum menguasai dan memahami program aplikasi SPSE (Sistem Pengadaan Secara Elektronik). Hal ini juga karena SDM yang ada tidak ada pelatihan khusus yang lebih intens untuk menambah keahlian dalam hal tersebut".

Berdasarkan hasil wawancara dengan beberapa informan maka dapat disimpulkan bahwa belum ada upaya peningkatan sumber daya manusia sehingga tidak SDM yang ada belum memiliki keahlian tentang eprocurement melalui pengadaan kegiatan seminar, pelatihan, dan kursus apalagi untuk lulus Ujian sertifikasi pengadaan barang/jasa pemerintah.

Jika dikaitan dengan peningkatan jumlah lelang yang dilakukan setiap tahunnya, sedangkan jumlah staf yang dapat ditugaskan sebagai pelaku pengadaan dari tahun ketahun tidak mengalami peningkatan yang signifikan baik yang iringi dengan peningkatan kompetensi staf yang ditugaskan untuk mengikuti pelatihan dan sertifikasi pengadaan barang/jasa tingkat dasar.

Padahal menurut Hasibuan (2014) Sumber Daya Manusia (SDM) merupakan salah satu faktor yang sangat penting bahkan tidak bisa dilepaskan dari sebuah organisasi. Yang pada hakikaktnya,SDM atau Sumber Daya Manusia adalah orang-orang yang dipekerjakan di suatu organisasi yang nantinya akan menjadi penggerak untuk bisa mencapai tujuan organisasi itu sendiri. Selain itu manusia yang memiliki SDM bagus biasanya diharapkan mampu berkontribusi terhadap perusahaan dimana itu bekerja. Sehingga
Sumber Daya Manusia (SDM) menjadi unsur utama dalam setiap aktivitas yang dilakukan. Kalaupun menggunakan peralatan yang canggih dan handal namun tanpa dibarengi peran aktif SDM yang baik, peralatan tersebut tidak akan bekerja secara maksimal.

2. Teknologi

Kemajuan teknologi informatika yang begitu pesat, membuka pemikiran untuk pengembangan e-government sebagai salah satu cara untuk mengelola administrasi publik dengan lebih cepat, murah dan transparan. Salah satu bentuk e-government yang dilakukan adalah layanan publik dalam pengadaan barang dan jasa di instansi pemerintah menggunakan Sistem Pelelangan Secara Elektronik (SPSE) atau yang lebih dikenal dengan e-procurement. Instrumen ini memanfaatkan fasilitas teknologi komunikasi dan informasi meliputi pelelangan umum secara elektronik yang diselenggarakan Layanan Pengadaan Secara Elektronik (LPSE).

Penerapan e-procurement bertujuan untuk melakukan efisiensi biaya berupa penurunan biaya operasional dan penurunan risiko terjadinya penyimpangan dalam pengadaan barang dan jasa. Investasi yang dilakukan perlu dinilai kelayakannya dengan mengukur keefektifan pelaksanaan eprocurement. Analisis atas proses bisnis menunjukkan bahwa e-procurement dapat meningkatkan transparansi, sehingga dapat mengurangi risiko terjadinya penyimpangan dalam proses pengadaan barang/jasa.

Sebagaimana tuntutan menyelenggarakan sistem pelayanan 
pengadaan barang/jasa secara elektronik (SPSE) Satuan Kerja Pelaksana Jalan Nasional Provinsi Kalimantan Tengah dalam melaksanakan pengadaan barang/jasa secara elektronik melayani registrasi penyedia barang dan jasa yang berdomisili di wilayah kerja Provinsi Kalimantan Tengah.

Pada dasarnya tahapan-tahapan dalam tender untuk setiap jenis pengadaan barang/jasa berbeda. Secara garis besar tahapan sebuah lelang elekronik dapat dilihat dalam jadwal yang tertera dalam situs yang ada. Adapun tahapan lelang eletronik yang ada di Satuan Kerja Pelaksana Jalan Nasional Provinsi Kalimantan Tengah adalah merupakan jenis pengadaan Pekerjaan Konstruksi yang secara garis besar tahapan tersebut sebagai berikut :

Gambar 4.I Jadwal Tender SATKER PJN Provinsi Kalimantan Tengah

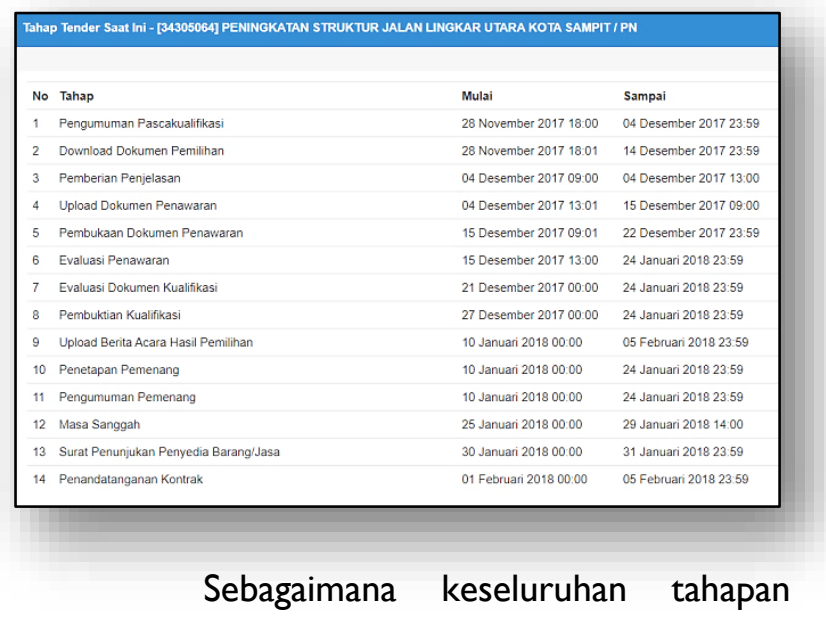

lelang yang dilakukan di Satuan Kerja PJN Provinsi Kalimantan Tengah secara elektonik tersebut merupakan tahapan lelang yang cukup panjang melalui I 4 tahap dan semuanya melalui teknologi. Namun, Teknologi yang ada di Satuan Kerja PJN Provinsi Kalimantan Tengah memiliki kendala yang disampaikan oleh Pokja Pemilihan yang mengungkapan :
"Proses lelang elektonik ini semuanya menggunakan sistem SPSE, selama ini kami akui bahwa ada keterbatasan kapasitas server dan kecepatan internet yang digunakan pokja dalam melaksanakan Pengadaan barang/jasa, khususnya untuk kecepatan internet akan terasa lambat sekali jika line internet yang tersedia juga digunakan bersamaan oleh pegawaipegawai yang lain".

Hal senada juga diungkapkan oleh pejabat pembuat komitmen yang mengatakan

"Selama dilakukannya lelang secara elektronik, kendala yang sering dialami adalah akses internet yang kecepatannya rendah sehingga memperlambat proses pada sistem, apalagi jika digunakan untuk mengupload persyaratan teknis pekerjaan konstruksi yang rata-rata mempunyai ukuran file yang besar, terutama file spesifikasi teknis dan file gambar rencana pekerjaan".

Hal serupa juga dikuatkan oleh pokja pemilihan yang sering ditugaskan untuk mengupload dan mendownload file melalui sistem SPSE, dia menyampaikan bahwa :

"Sering sekali terjadi kendala dalam upload (mengunggah) dan mendownload (mengunduh) dokumen, mengingat banyak dokumen yang harus di-upload dan di-download dan semuanya ada pada sistem pengadaan barang/jasa secara ektonik. Jika akses internet yang kecepatannya rendah akan memakan waktu yang lama dalam mengupload (mengunggah) dokumen tender dan mendownload (mengunduh) dokumen penawaran peserta, khusunya jika ukuran file tersebut > 100Mb".

Dari berbagai pernyataan terkait dengan teknologi yang di gunakan dalam pelaksanaan e-procurement dapat disimpulkan bahwa sisi teknologi ini terjadi kendala dari Kecepatan akses internet yang rendah sehingga terkadang masih lambat serta kapasitas server yang terbatas. Hal ini menjadi 
kendala bagi Pokja Pemilihan/Penyedia Jasa saat proses upload dan download dokumen tender.

\section{Faktor-faktor Penghambat Pelaksanaan}

\section{Pengadaan Barang/Jasa Elektronik}

I. Bidang SDM

Masih banyak pegawai yang belum menguasai dan memahami program aplikasi SPSE (Sistem Pengadaan Secara Elektronik), sehingga diperlukan pelatihan khusus yang lebih intens. Masih banyak pegawai yang belum memiliki Sertifikat Pengadaan Barang/Jasa Pemerintah karena susahnya untuk lulus Ujian sertifikasi pengadaan barang/jasa pemerintah

\section{Bidang Teknologi}

Kecepatan akses internet yang terkadang masih lambat serta kapasitas server yang terbatas. Hal ini menjadi kendala bagi Pokja Pemilihan/Penyedia Jasa saat proses upload dan download dokumen tender.

\section{KESIMPULAN}

I. Pelaksanaan Pengadaan Barang/jasa secara elektonik pada satuan kerja pelaksanaan jalan nasional Provinsi Kalimantan Tengah telah dilakukan sejak beberapa tahun terakhir. Seluruh tahapan lelang secara elektonik itu melalui proses yang panjang yakni dengan 14 tahapan yang semuannya tranparan menggunakan sistem yang bisa diakses untuk publik.

2. Faktor penghambat pelaksanaan pengadaan barang/jasa secara elektronik (eprocurement) pada satuan kerja pelaksanaan jalan nasional Provinsi Kalimantan Tengah yaitu :

a. SDM, yaitu kurangnya keahlian dalam menjalankan aplikasi Sistem Pengadaan Secara Elektronik (SPSE) serta kurangnya pegawai yang memiliki Sertifikat Pengadaan Barang Jasa yang merupakan syarat mutlak untuk menjadi Pokja Pemilihan/Pejabat Pengadaan.

b. Teknologi, kapasitas jaringan internet yang menyebabkan kecepatan akses internet menjadi lambat.

\section{SARAN}

I. Dari segi SDM dengan meningkatkan kegiatan sosialisasi mengenai Tender Elektronik (eprocurement), meningkatan kegiatan pelatihan tentang pelaksanaan pengadaan barang/jasa pemerintah agar pegawai dapat lulus ujian sertifikasi pengadaan barang/jasa pemerintah, meningkatkan jumlah honor/tunjangan yang diterima pelaku pengadaan (pokja/pejabat pengadaan) sehingga lebih memberikan semangat kepada pegawai untuk terlibat dan lebih mendalami ilmu tentang pengadaan barang/jasa pemerintah.

2. Dari segi teknologi, perlu menambah bandwitdh internet dan kapasitas server SPSE, perlu disediakan jaringan internet khusus bagi pokja/pejabat pengadaan sehingga hanya pokja/pejabat pengadaan itu saja yang menggunakan akses internet khusus tersebut, tidak berbagi dengan pegawai lain yang tidak terlibat dalam proses pengadaan barang/jasa. 


\section{REFERENSI}

Anggara, Sahya. (2012). Ilmu Administrasi Negara. Bandung : CV.Pustaka Setia.

Agustino, Leo. (20I4). Dasar-Dasar Kebijakan Publik. Bandung: CV.Alfabeta.

Mulyadi Dedy. (20I5). Studi Kebijakan Publik dan Pelayanan Publik. Bandung: Alfabeta.

Nurchana, A. R. A. (20/4). Efektivitas EProcurement dalam Pengadaan Barang/Jasa (Studi terhadap Penerapan E-Procurement dalam Pengadaan Barang/Jasa di Kabupaten Bojonegoro). Jurnal Administrasi Publik 2(2), 355-359.

Pasolong,harbani. (20/3). Teori Administrasi Publik. Bandung: CV.Alfabeta.

Safari, Faruq. (2020). Manajemen Pengendalian Pelaksanaan Kontrak Pengadaan Barang/Jasa Pemerintah Di Kantor Wilayah Kementerian Agama Provinsi Kalimantan Tengah. Tesis. Universitas Muhammadiyah Palangkaraya.

Tahir Arifin. (20I4). Kebijakan Publik \& Transparansi Penyelenggaraan Pemerintah Daerah. Bandung : Alfabeta.

Tombak, Albert. (20/8). Sistim Layanan Pengadaan Barang/Jasa Secara Elektronik di Kota Palangka Raya. Tesis. Universitas Muhammadiyah Palangkaraya.

Wahab, Solichin Abdul. (20I5). Analisis Kebijaksanaan Dari Formulasi ke Penyusunan Model-Model Implementasi Kebijakan Publik. Malang : Bumi Aksara.

Widodo, Joko. (2016). Analisis Kebijakan Publik. Malang : Media Nusa Creative.

Winarno, Budi. (20I4). Kebijakan Publik (Teori, Proses dan Studi Kasus). Caps. Yogyakarta. 